This work is licensed under a Creative Commons Attribution 4.0 International License.

Ovaj rad dostupan je za upotrebu pod međunarodnom licencom Creative Commons Attribution 4.0.

\title{
NOMEN EST OMEN. ONIMI KAO SASTAVNICE HRVATSKIH I ENGLESKIH FRAZEMA
}

Dunja Zoričić, Sveučilište u Rijeci, Medicinski fakultet, dunja.zoricic@gmail.com, Rijeka

izvorni znanstveni članak

UDK 811.163.42'373.7

811.111 '373.7

rukopis primljen: 8. travnja 2019; prihvaćen za tisak: 2. listopada 2019.

U ovome se članku kontrastivno analiziraju odabrani hrvatski $i$ engleski frazemi leksičkog polja onima. Riječ je o frazemima kojima je sastavnicom vlastito ime, odnosno toponim, etnonim ili antroponim. Cilj je rada bio provesti kontrastivnu analizu navedenih frazema da bi se utvrdile podudarnosti, sličnosti i razlike hrvatske i engleske onimijske frazeologije. Također se u odnos stavljaju dvije kulture različite prošlosti i sociolingvističke pozadine, jedne anglosaksonske, druge slavenske. Polazište analize su hrvatski frazemi za koje se tražilo izrazne i/ili sadržajne ekvivalente. Kontrastivnom su analizom frazemi podijeljeni u tri skupine kroz koje se uočavaju njihove podudarnosti $i$ različitosti, odnosno daje se pregled posebnosti dvaju frazeoloških fondova uvjetovanih kulturološkom, socijalnom, političkom, povijesnom ili nekom drugom značajkom.

Ključne riječi: hrvatskijezik; engleskijezik; frazem; frazeologija; kontrastivna analiza; onim

\section{Uvod}

Sve je intenzivnija tendencija proučavanja sadržaja, odnosno prirode vlastitih imenica te pitanja funkcije koju one nose nasuprot općim imenicama. Tradicionalna lingvistika na vlastite imenice gleda kao na 
leksičke jedinice čija je (jedina) funkcija ona referencijalna, identifikacijska te striktno vezana za jednu osobu ili jedan objekt, dok su opće imenice te koje imaju značenje i mogu biti punoznačne riječi. No u novije vrijeme vlastite se imenice promatraju kroz prizmu kognitivne lingvistike te se na njih gleda kao na riječi koje u određenom semantičkom kontekstu mogu poprimiti funkciju opće imenice. $S$ vremenom ta vlastita imenica i izvan tog konteksta poprima konotativnu funkciju opće imenice, pa se može govoriti o omnipersonalnoj uporabi imena (Marković 2010: 191).

Proučavanjem nastanka i značenja vlastitih imena bavi se onomastika, a ova je lingvistička grana prisutna i u frazeologiji. Područje frazeologije izuzetno je zanimljivo ne samo u kontekstu lingvistike, pragmalingvistike, sociolingvistike te općenito filologije, već je i sastavni dio inih humanističkih i društvenih znanosti kao što su etnologija, psihologija i kulturologija, a kojima se nastoji etimološki proučavati i nacionalno očuvati živopisno leksičko blago koje svaki narod i njegovo kulturnojezično naslijeđe čini jedinstvenim i specifičnim.Za razliku od slobodnih sveza u kojima svaka od sastavnica zadržava svoje značenje, u frazeološkim svezama „dolazi do promjene odnosno gubitka značenja svih ili nekih sastavnica (barem jedne od njih), pa značenje cijele sveze ne proistječe iz značenja pojedinih sastavnica. Takve se sveze rabe kao gotove, cjelovite jedinice, tako da ne nastaju u govornom procesu, nego su govorniku unaprijed poznate, na neki način zadane: on ne bira sastavnice, nego gotovu svezu" (Menac 2007: 9).

U ovome se radu uspoređuju engleski i hrvatski frazemi leksičkog polja onima. Kriterij za odabir građe i njenu analizu bio je postojanje barem jedne sastavnice koja predstavlja vlastito ime, točnije toponim, etnonim ili antroponim. Pritom su u građu ulazili i frazemi čijom su sastavnicom posvojni pridjevi nastali od vlastitih imenica. Svrha je rada uočiti podudarnosti i razlike onimijskih frazema dviju kultura različite prošlosti i sociolingvističke pozadine, jedne anglosaksonske, druge slavenske te objasniti pozadinsku sliku i motivaciju manje poznatih onimijskih frazema. Budući da već postoje znanstveni radovi koji se bave pregledom i analizom (etimologije) hrvatskih onimijskih frazema ${ }^{1}$, u ovome se radu daje pregled podrijetla uglavnom engleskih onimijskih frazema.

Građa za hrvatske i engleske frazeme prikupljena je iz Hrvatskog frazeološkog rječnika Antice Menac, Željke Fink-Arsovski i Radomira Venturina,

1 Vidi popis literature. 
Hrvatsko-engleskog frazeološkog rječnika Dalibora Vrgoča i Željke FinkArsovski, Hrvatsko-engleskog frazeološkog rječnika Ivane Bendow, kao i autoričinog Englesko-hrvatskog frazeološkog rječnika te iz engleskih frazeoloških rječnika Oxford Dictionary of Idioms, Longman Pocket Idioms Dictionary i Cambridge International Dictionary of Idioms ${ }^{2}$. Frazemi engleskoga jezika dijelom su prikupljeni i na internetu te je njihova etimologija istražena s pomoću pretraživača Google $e^{3}$.

\section{Onomastika - nomen est omen}

Vladimir Anić i Ivo Goldstein definiraju onomastiku kao granu lingvistike koja „izučava značenje i nastanak vlastitih imena”, odnosno kao „ukupnost vlastitih imena (osobnih, obiteljskih, mjesnih) koja se pojavljuju na nekom etničkom, geografskom ili jezičnom području" (2000: 940). Onomastika se obično dijeli na antroponimiju (ukupnost imena ljudi) i toponimiju (ukupnost imena lokaliteta). Antroponimija obuhvaća realnu antroponimiju (osobna imena, prezimena i nadimke stvarnih ljudi i imena svetaca) i fiktivnu antroponimiju (imena mitoloških bića, božanstava te imena likova iz književnih djela). Toponimija se dijeli na primarnu (dokumentirana i dobro poznata imena) i sekundarnu (novija imena koja se javljaju sukladno razvoju i širenju lokaliteta). Iako se toponimi mogu podijeliti po vrsti i tipu imenovanja, najčešća je podjela toponima na ekonime (imena naseljenih mjesta), oronime (imena gora i uzvisina) i hidronime (imena voda, rijeka i jezera). Polje etnonimije podrazumijeva etnike (imena stanovnika naseljenih mjesta, regija, država i kontinenata), egzonime (naziv nekoga mjesta drugačiji od onoga u mjestu ili zemlji kojoj pripada) i etnonime (imena naroda). Bionime dijelimo na zoonime (nazivi vrsta životinja) i fitonime (nazivi sorti biljaka) (Vuković 2007: 147-157).

Čest je slučaj da kod pojedinih onima dolazi do procesa apelativizacije i deonimizacije zahvaljujući kojima (vlastita) imenica postaje sastavnim dijelom leksičkoga fonda određenog jezičnog sustava (Barac-Grum 1990: 15; Peti 1999: 108; Brozović Rončević, Žic Fuchs 2003/2004: 92; Opašić

\footnotetext{
2 Zbog velikoga broja pronađenih hrvatskih i engleskih frazema s onimskom sastavnicom rad je ograničen na građu prikupljenu iz leksikografskih izvora, izostavljajući iz analize korpusno istraživanje frazema. Stoga ovaj rad ne pretendira da bude konačan i cjelovit pregled hrvatskih i engleskih frazema s onimskom sastavnicom koji pripadaju korpusima dvaju analiziranih jezika.

3 Internetski izvori navedeni su u popisu literature na kraju rada.
} 
2014: 502). Takve su, na primjer, biblijski motivirane riječi juda ('izdajica'), golgota ('velike muke, mučeništvo, simbol trpljenja i ispaštanja'), baraba ('onaj koji je bez potrebnih dobrih svojstava u ljudskom društvu, grub, prost i nasilan čovjek; ološ, propalica'), jeremija ('onaj koji se stalno žali, onaj koji stalno kuka') i samaritanac ('milosrdan čovjek'), gdje prijelaz onima u apelativ sa sobom može povlačiti i dodatno, šatrovačko ili pejorativno značenje ${ }^{4}$.

Siniša Vuković (2007: 141-142) tvrdi da je onomastika interdisciplinarna znanost jer svako govorenje o onomastičkoj građi podrazumijeva poznavanje drugih znanosti kao što su povijest, geografija, etimologija, mitologija i slično. Primjerice, antroponim Metuzalem podrazumijeva poznavanje biblijske priče o najstarijem čovjeku koji je doživio 969. godinu, a čije je ime danas sinonim za vrlo staru osobu, odnosno za čovjeka u vrlo visokoj životnoj dobi. To potvrđuje i hrvatski frazem star kao Metuzalem značenja 'jako (vrlo) star', ali i engleski frazem since the days of Methuselah, čiji je hrvatski ekvivalent frazem od pamtivijeka.

U ovom kontekstu valja spomenuti i (konceptualnu) metaforu i metonimiju kao „temeljne kognitivne procese prisutne ne samo u jeziku nego u gotovo svim domenama ljudskog djelovanja" (Brdar, Brdar-Szabó 2001: 35). George Lakoff, za kojega se može reći da je među prvima koji su proširili polje (funkcije) metafore i isticali važnost uloge čovjekova konceptualnoga sustava u objašnjavanju metafore u jeziku, tvrdi: „Bit je metafore u tome da jednu stvar razumijemo i doživljavamo kao neku drugu" (Lakoff, Johnson 1980: 4). I dok je za konstruiranje značenja kod konceptualne metafore nužno postojanje dvije konceptualne domene, izvorne i ciljne koje se preslikavaju jedna na drugu (Stanojević 2013: 54), za metonimiju je karakteristično preslikavanje unutar jedne konceptualne domene (Brdar, Brdar-Szabó 2001: 36).

Ta su preslikavanja vidljiva i u onomastici, pa kad se kaže Na zidu mi visi Rembrandt mislimo, naravno, na umjetničku sliku poznatoga slikara, stoga se ovdje radi o metonimiji. Primjer metafore vidljiv je u sljedećoj rečenici: Tko su Don Juani koji osvajaju žene? ${ }^{5}$ Ovaj nebrojeno puta opjevan književni lik danas je postao sinonimom za ženskara ('onaj koji rado i često

\footnotetext{
4 V. više u Opašić 2014: 504-508.

5 http://www.intimatemedicine.com.hr/enciklopedija-seksualnosti/partnerski-odnosi/ partnerski-problemi/zenskar/tko-su-don-juani-koji-osvajaju-zene (pristupljeno 21. studenoga 2019.)
} 
osvaja žene, onaj koji juri za suknjama'), a bio je i poticajem za tvorbu apelativa donžuan ('zavodnik, pustolov, avanturist'). Isti je slučaj $s$ apelativima sodomija ('seksualna nastranost, osoba koja uživa u snošaju sa životinjama') i glembajevština ('stanje duhova i način života opisan u prozno-dramskom ciklusu o Glembajevima M. Krleže'), kao i s opisnim pridjevima orvelovski ('koji se odnosi na stanje tjeskobe i nemoći čovjeka pritisnutog totalitarnim režimom, svemoćnom silom vlasti i dehumanizacijom') i donkihotovski ('koji se odnosi na čovjeka koji ima nestvarne ideale i koji uzaludno gubi vrijeme da bi ih postigao'). Kao razloge apelativizacije vlastitih imena u nekom jeziku Vida Barac-Grum (1990: 18) navodi potrebu za širenjem jezičnoga leksika te težnju za nijansiranjem određenih pojmova. Važno je spomenuti i da su ovakvi primjeri najvjerniji pokazatelj ekonomičnosti jezika, ali i utjecaja književnosti na jezični fundus svakodnevice.

\section{Onim kao sastavnica frazema}

Vlastito ime može se javiti i kao jedna od sastavnica frazema. Onimi u frazemima mogu biti imenice ili pridjevi, a obuhvaćaju antroponime (Arijadnina nit, mudar kao Solomun), etnonime (pušiti kao Turčin, pijan kao Rus) i toponime (sve u redu k’o u Beču, briga koga što Mađarska nema mora). „Vlastito ime kao sastavnica frazema može biti važnim i vrlo sigurnim pokazateljem njegova podrijetla" (Opašić 2014: 415). Prema tome, isto kao što je moguće podijeliti frazeme na uopćenoj razini, i frazeme s onimskom sastavnicom prema podrijetlu možemo podijeliti na nacionalne (Martin u Zagreb, Martin iz Zagreba, i mirna Bosna), biblijski motivirane frazeme (od Adama <i Eve >, nevjerni Toma), frazeme s povijesnim ili mitološkim onimima (posljednji Mohikanac, zajahati Pegaza) te ostale općeeuropske frazeme (Nešto je trulo u državi Danskoj) (Turk 1994: 38-42).

Povijesno, mitološko i biblijski motivirani frazemi u sebi sadržavaju kontekst i identifikaciju određene osobe u njemu. Kad se za nekoga kaže da je strpljiv kao Job ('vrlo strpljiv') ili da prolazi Tantalove muke ('velike poteškoće, nesnosne patnje'), poželjno je poznavati etimologiju frazema i ulogu povijesne, mitološke ili biblijske osobe u njoj, točnije osobine koja je tu osobu „pretvorila” u ime-simbol. Za razliku od njih, kod nacionalnih frazema „svako ime [...] može postati osnova za tvorbu apelativa, odnosno može primiti širi semantički kontekst i apelativizirati se" (Vida Barac-Grum 1990: 17). Za takve je onime karakteristična deonimizacija u trenutku 
ulaska u sastav frazema, što samo potvrđuje njihovu omnipersonalnu uporabu.

Frazemi s onimskom sastavnicom iznimno su plodno područje, posebice za sociolingviste, jer je kroz njih moguć uvid u strano i vlastito. Mogu biti pokazateljem tipičnih osobina nekoga naroda, u što ulaze i iskustva $s$ drugim narodima kao i percipiranje njihovih navika i običaja. Nerijetko takvi onimijski frazemi reflektiraju stereotipne predodžbe, odnosno pripisivanje pozitivnih ili negativnih osobina društvenim skupinama, njihovim članovima ali i njihovim „domaćim” proizvodima (Ivanetić, Karlavaris-Bremer 1999: 132-133). Primjerice, etnonimi u frazemima pušiti kao Turčin ('mnogo pušiti, biti veliki pušač'), pijan kao Rus ('jako pijan') i raditi kao Švaba ('marljivo raditi') otkrivaju pretpostavku hrvatskoga naroda o ponašanju, odnosno o lošim navikama Turaka i Rusa te marljivosti Nijemaca. Pritom je bitno spomenuti i utjecaj koji su oba naroda imala na hrvatsku povijest, a sličan je slučaj razvidan i među drugim povijesno i kulturno povezanim narodima ${ }^{6}$. Isto tako, frazemi biti pun rupa kao švicarski sir ('biti pun propusta, nedostataka') i točan kao <švicarski> sat ('vrlo točan, točan u minutu') koji se javljaju i u drugim jezicima te frazem imati albanske svjećice ('biti usporen u razmišljanju, sporo zaključivati') pokazuju i stav govornika prema proizvodima koji su zbog svoje (ne)funkcionalnosti postali zaštitnim znakom nekog naroda.

\section{Građa hrvatskih i engleskih onimijskih frazema}

Na temelju frazema prikupljenih iz leksikografske građe, u ovome se radu uspoređuju engleski i hrvatski frazemi leksičkog polja onima. Kriterij za odabir građe i njenu analizu bio je postojanje barem jedne sastavnice koja predstavlja vlastito ime, točnije toponim, etnonim ili antroponim. Pritom su u građu ulazili i frazemi čijom su sastavnicom posvojni pridjevi nastali od vlastitih imenica. Svrha je rada utvrditi podudarnosti i razlike onimijskih frazema dviju kultura različite prošlosti i sociolingvističke pozadine, jedne anglosaksonske, druge slavenske te objasniti pozadinsku sliku i motivaciju manje poznatih onimijskih frazema čije je podrijetlo poznato.

Kao što je već navedeno, u ovome je radu polazišni jezik kontrastivne analize hrvatski jezik i njegov frazeološki fond. Kao rezultat kontrastivne

6 V. više u Ivanetić, Karlavaris-Bremer 1999. 
analize, dobivene su tri skupine hrvatskih i engleskih frazema s onimskom sastavnicom:

1. potpuna podudarnost (jednak izraz $\mathrm{i}$ isti onim)

2. djelomična podudarnost (isti onim, ali djelomično ili potpuno različit izraz)

3. nepodudarnost (različit izraz i različit onim/ili onima nema).

Budući da se skupina potpuno nepodudarnih hrvatskih i engleskih frazema s onimskom sastavnicom pokazala najvećom (57,4\%), cilj je analize promotriti hrvatski i engleski kao dva prostorno i geneološki udaljena jezika te uočiti njihove različitosti i posebnosti uvjetovane kulturološkom, socijalnom, političkom, povijesnom ili nekom drugom značajkom.

\subsection{Potpuna podudarnost hrvatskih i engleskih frazema}

Ova skupina broji 47 hrvatskih i engleskih frazema koji imaju isti onim i leksički jednake izraze, te samim time i podudarnu pozadinsku sliku (Tablica 1.), što čini 36,4\% ukupne prikupljene građe. Najbrojniji su frazemi mitološkoga podrijetla, nakon kojih u jednakom broju slijede biblijski i povijesno motivirani frazemi. Ostalih frazema ima najmanje, a čine ih frazemi književne provenijencije (veliki brat - Big Brother, kvaka 22 - Catch 22) te frazem a black day (Friday) ('nesretan dan') čiji onim u hrvatskome jeziku nema jednak status kao u engleskome. Naime, ovaj frazem u anglosaksonskoj povijesti upućuje na dva događaja. Prvi se odnosi na zloglasni petak, 24. rujna 1869. godine, kada su špekulanti izazvali veliku financijsku paniku na tržištu zlata. Drugi se događaj odnosi na dan nakon Dana zahvalnosti. Naime, ovaj američki praznik uvijek se obilježava četvrtog četvrtka u studenome, nakon čega slijedi jedan od najprometnijih dana za kupovinu kada trgovci nude velike popuste ${ }^{7}$.

Ova je skupina očekivano pokazala potpunu podudarnost frazema za koje je karakteristično da su prevođeni i prošireni u mnogim jezicima, zbog čega ih smatramo općeeuropskim frazemima (Turk 1994: 38). S obzirom na to da postoje brojni znanstveni radovi u kojima se daje pregled i analiza frazema s biblijskim, povijesnim i mitološkim onimima, detaljnijoj analizi bit će podvrgnuti onimijski frazemi motivirani javnim ličnostima i događajima, kao i frazemi koji ocrtavaju stereotipe i vjerovanja karakteristična za govornike dvaju analiziranih jezika.

7 www.dictionary.reference.com (pristupljeno 3. travnja 2018.) 
Tablica 1. Potpuno podudarni hrvatski i engleski frazemi

\begin{tabular}{|l|l|}
\hline \multicolumn{1}{|c|}{ Hrvatski frazem } & \multicolumn{1}{c|}{ Engleski frazem } \\
\hline od Adama <i Eve> & <ever> since Adam <and Eve> \\
\hline Pandorina kutija & a Pandora's box \\
\hline Damoklov mač & the sword of Damocles \\
\hline star kao Metuzalem & <as> old as Methuselah \\
\hline posljednji Mohikanac & the last of the Mohicans \\
\hline Tantalove muke & the agonies of Tantalus \\
\hline Ahilova peta & sb's Achilles' heel \\
\hline Pirova pobjeda & a Pyrrhic victory \\
\hline Judin poljubac & Judas kiss \\
\hline Sizifov posao & a Sisyphean task (labour) \\
\hline prijeći/prelaziti Rubikon & cross the Rubicon \\
\hline izmedu Scile i Haribde & between Scylla and Charybdis \\
\hline nevjerni Toma & a doubting Thomas \\
\hline kopernikanski obrat & a Copernican revolution \\
\hline ostvariti američki san & realise the American dream \\
\hline Evina kći & daughter of Eve \\
\hline bogat kao Krez & as rich as Croesus \\
\hline Arijadnina nit & Ariadne's thread \\
\hline mudar kao Solomun & wise as Solomon \\
\hline Potemkinova sela & a Potemkin village \\
\hline Sodoma i Gomora & Sodom and Gomorrah \\
\hline džepna Venera & pocket Venus \\
\hline u Abrahamovu krilu & in Abraham's bosom \\
\hline Kolumbovo jaje & the egg of Columbus \\
\hline bartolomejska noć & St. Bartholomew's night \\
\hline zajahati Pegaza & mount Pegasus \\
\hline Prokrustova postelja & Procrustean bed \\
\hline Prometejev oganj & Promethean Fire \\
\hline homerski smijeh & Homeric laughter \\
\hline Augijine štale & the Augean stable(s) \\
\hline igrati ruski rulet & play Russian roulette \\
\hline Occamova britva & Occam's razor \\
\hline frojdovska omaška & a Freudian slip \\
\hline Murphyjev zakon & Murphy's Law \\
\hline
\end{tabular}




\begin{tabular}{|l|l|}
\hline \multicolumn{1}{|c|}{ Hrvatski frazem } & \multicolumn{1}{c|}{ Engleski frazem } \\
\hline majka priroda & Mother Nature \\
\hline svi putevi vode u Rim & All roads lead to Rome \\
\hline $\begin{array}{l}\text { ako neće Muhamed brijegu, mora brijeg } \\
\text { Muhamedu }\end{array}$ & $\begin{array}{l}\text { if Mohammed will not go to the mountain, } \\
\text { the mountain must go to Mohammed }\end{array}$ \\
\hline presjeći gordijski čvor & cut the Gordian knot \\
\hline trojanski konj & a Trojan horse \\
\hline kvaka 22 & Catch 22 \\
\hline solomunsko rješenje & a Solomon solution \\
\hline crni petak & a black day (Friday) \\
\hline kula babilonska & the Tower of Babel \\
\hline biti veći katolik od pape & be a bigger Catholic than the Pope \\
\hline veliki brat & Big Brother \\
\hline kolo sreće & the Wheel of fortune \\
\hline kad si u Rimu, ponašaj se kao Rimljanin & When in Rome do as the Romans do \\
\hline
\end{tabular}

\subsection{Djelomična podudarnost hrvatskih i engleskih frazema}

U ovoj skupini prikupljeno je 8 hrvatskih i engleskih frazema koji dijele isti onim, no svojim izrazom i strukturom te frazemskom pozadinskom slikom djelomično se ili pak potpuno razlikuju od hrvatskih onimijskih frazema (Tablica 2.). Skupina broji najmanje hrvatskih i engleskih frazema s onimskom sastavnicom iz analizirane građe (6,2\%), a među njima se nalaze dva biblijska frazema i jedan frazem mitološkoga podrijetla. Dva su frazema koja ukazuju na stereotipne predodžbe prema članovima nekog naroda, odnosno upućuju na svojstvo proizvoda nekog naroda (američka posla - as American as apple pie, biti pun rupa kao švicarski sir - have more holes than Swiss cheese). Frazem sijamski blizanci - be like Siamese twins nastao je determinologizacijom sintagme koja označava fenomen blizanaca čija su tijela sraštena in utero, dok bi značenje samog frazema bilo "bliskost i nerazdvojivost dviju osoba'. Preostala dva frazema ne pripadaju nijednoj skupini; frazemom princ iz bajke - Prince Charming žele se istaknuti pozitivne osobine kod muškarca o kakvom žene maštaju - 'muškarac iz mašte', a frazemom glumiti damu - play Lady Muck žele se raskrinkati negativne osobine pretenciozne žene - 'praviti se finom, hiniti finoću'. 
Tablica 2. Djelomično podudarni hrvatski i engleski frazemi

\begin{tabular}{|l|l|}
\hline \multicolumn{1}{|c|}{ Hrvatski frazem } & \multicolumn{1}{c|}{ Engleski frazem } \\
\hline princ iz bajke; princ na bijelom konju & Prince Charming \\
\hline glumiti damu & play Lady Muck \\
\hline biti pun rupa kao švicarski sir & have more holes than Swiss cheese \\
\hline američka posla & as American as apple pie \\
\hline sijamski blizanci & be like Siamese twins \\
\hline poći u Damask & your road to Damascus \\
\hline $\begin{array}{l}\text { pogodila je Amorova (Kupidova) strijela } \\
\text { (strelica) koga }\end{array}$ & be hit by Cupid's arrow \\
\hline strpljiv kao Job & the patience of Job/a saint \\
\hline
\end{tabular}

\subsection{Potpuna nepodudarnost hrvatskih i engleskih frazema}

Pod potpunom nepodudarnošću podrazumijevaju se primjeri u kojima se hrvatski i engleski frazemi razlikuju svojim izrazom i onimskom sastavnicom, pa zbog toga govorimo o frazemima nepodudarne pozadinske slike (Tablica 3.). Takvih je hrvatskih i engleskih frazema za potrebe ovoga rada prikupljeno 74, što čini $57,4 \%$ ukupne prikupljene građe. Značenje je engleskih frazema ove skupine najvećim dijelom semantički neprozirno, što se možda može pripisati i živopisnoj idiomatskoj slici koja potpuno nepodudarne frazeme dvaju jezika dovodi u suprotstavljen odnos. Među hrvatskim frazemima u ovoj skupini prevladavaju frazemi koji nisu vezani uz biblijsku, mitološku ili povijesnu priču, ili im je podrijetlo nepoznato. Zatim slijede frazemi povijesnog i biblijskog podrijetla, a najmanje je mitološki motiviranih frazema. Ista je situacija i s njihovim engleskim ekvivalentima.

Tako se na suprotnoj strani hrvatskim i engleskim onimijskim frazemima nalaze ekvivalenti kojima onimska sastavnica nije potrebna da bi frazemima svoga jezika oslikali ljudske osobine ili životne okolnosti. Hrvatski frazem lud sto gradi stoji nasuprot engleskome onimijskome frazemu <as > mad as a March hare. Sastavnica March u ovome frazemu stoji za mjesec ožujak, a tada se, prema nekima, zečevi ponašaju neuobičajeno zbog parenja. Taj je idomatični izraz iz 16. stoljeća popularizirao i Lewis Carroll uvevši lik Ožujskoga Zeca u svoje djelo Alisa u zemlji čudesa ${ }^{8}$. Nadalje,

8 www.phrases.org.uk (pristupljeno 20. studenoga 2019.) 
nepodudarni engleski ekvivalent frazemu graditi kule u zraku (oblacima) je engleski izraz build castles in Spain. Ovaj frazem francuskoga podrijetla datira još s početka 14. stoljeća, a povijesno je motiviran vremenom kada je Španjolska bila pod okupacijom Maura te je predstavljala neprobojno područje koje Francuzi nisu mogli osvojiti niti ondje graditi dvorce ${ }^{9}$.

Nasuprot hrvatskome onimijskome frazemu stajati (koštati) <koga> kao svetog Petra kajgana stoji engleski nepodudarni ekvivalent bez onima cost $\langle\mathrm{sb}\rangle$ an arm and a leg. Ovaj engleski frazem datira iz vremena nakon Drugoga svjetskoga rata. Budući da je to mučno razdoblje obilježeno ratnim razaranjima u kojima su mnogi (američki) vojnici izgubili svoje ekstremitete, pretpostavlja se da je izraz referenca na veliku patnju koju su ti ljudi prolazili, ali i referenca na veliku vrijednost koju nose ovi ekstremiteti ${ }^{10}$.

Hrvatski frazem soliti more stoji nasuprot engleskome onimijskome frazemu take coals to Newcastle. Ovaj engleski izraz čije je značenje 'raditi suvišan, besmislen posao' prvi je put zabilježen u 17. stoljeću, a slične je frazeme moguće pronaći i u drugim jezicima (selling snow/ice to Eskimos, selling sand to Arabs, voditi goluba u Veneciju $)^{11}$.

Zanimljiva je i etimologija engleskoga frazema it's a Chinese fire drill čiji je hrvatski nepodudarni ekvivalent ne zna se tko pije ni tko plaća. Naime, posvojni pridjev „kineski” u engleskome jeziku ima pejorativno značenje još od razdoblja Prvoga svjetskoga rata i prvih europsko-kineskih odnosa. Britanski su vojnici nesposobne pilote nazivali Chinese aces, za gruba su slijetanja imali naziv Chinese landing, a svaku bi zbunjujuću i neorganiziranu situaciju prozvali Chinese fire drill. Podrijetlo ovoga izraza seže s početka 20. stoljeća, kada su časnici na jednome britanskome brodu provodili vatrogasnu vježbu u kojoj je kineska posada imala ulogu „ljudskog lanca” za prijenos posude $s$ vodom $s$ jednog kraja broda na drugi. Iako je cilj te vatrogasne vježbe bio ugasiti požar u strojarnici, naredbe su se tijekom izvođenja vježbe pobrkale i voda nikada ne bi završila u strojarnici ${ }^{12}$.

Hrvatskome frazemu dobiti šipak engleski onimijski ekvivalent je get sweet Fanny Adams. Ovaj frazem morbidnoga podrijetla veže se uz priču o

\footnotetext{
9 https://grammarist.com (pristupljeno 18. studenoga 2019.)

10 www.phrases.org.uk (pristupljeno 19. svibnja 2018.)

11 www.phrases.org.uk (pristupljeno 11. svibnja 2018.)

12 http://mentalfloss.com/article/52989/what\%E2\%80\%99s-origin\%E2\%80\%9Cchinese-fire-drills (pristupljeno 8. travnja 2018.)
} 
osmogodišnjoj djevojčici Fanny Adams koja je brutalno ubijena 1867. godine, a čije je osakaćeno tijelo pronađeno u polju nedaleko od grada Altona u Velikoj Britaniji. Priča je ubrzo digla stanovništvo na noge, a njezino je ime postalo sinonimom za mlade nedužne žrtve ubojstva. Nedugo nakon toga članovi britanske Kraljevske ratne mornarice opravdali su status okrutnoga britanskoga humora te su ime djevojčice počeli koristiti kao referencu na neukusnu konzerviranu mesnu hranu. Ime Fanny Adams tek je kasnije dobilo značenje 'apsolutno ništa', a početkom 20. stoljeća zabilježeno je eufemistično značenje inicijala ovoga imena (F.A.) koji se igrom slučaja poklapaju s pejorativnim izrazom fuck all (Oxford Dictionary of Idioms 2004: 283).

Nasuprot hrvatskome frazemu smijati se od uha do uha nalazi se engleski onimijski frazem grin like a Cheshire cat. Ovaj je frazem populariziran romanom Alisa u zemlji čudesa Lewisa Carrolla iz 1865. godine, u kojoj je jedan od likova upravo istoimeni mačak s prepoznatljivim osmijehom od uha do uha. No podrijetlo ovoga frazema datira s početka 19. stoljeća. Naime, Cheshire je pokrajina u Velikoj Britaniji poznata po proizvodnji sira i mliječnih proizvoda, a upravo su se zbog toga sirevi oblikovali u liku mačke. Izvori također bilježe nespretne znakove diljem spomenute pokrajine koji su trebali oslikavati lava koji riče, no taj je lav izgledao kao mačka koja se ceri ${ }^{13}$.

Engleski ekvivalent hrvatskome frazemu lako je biti general poslije bitke je onimijski frazem a Monday morning quarterback. Ovaj frazem u doslovnom bi prijevodu glasio „(biti) vođa navale u ponedjeljak ujutro”, a svoje podrijetlo vuče iz sporta, točnije američkog nogometa. Naime, vođa navale zadužen je za organiziranje napada i dodavanje lopte hvatačima, a taj je izraz u američkom engleskom dobio i dodatno značenje - 'osoba koja organizira i vodi neki posao ili projekt'(Oxford Dictionary of Idioms 2004: 191).

Analiza građe pokazala je da postoje i parovi hrvatskih i engleskih frazema s drugačijim onimima, što je vrijedan podatak iz kojega se mogu iščitati brojne kulturno-povijesne priče i specifičnosti običaja hrvatskoga i engleskoga naroda. Takvi su primjeri: i mirna Bosna ${ }^{14}$ - and Bob's your uncle,

\footnotetext{
13 https://grammarist.com (pristupljeno 20. studenoga 2019.)

14 Frazem odražava vjekovno povijesno iskustvo. Naime, prostor Bosne oduvijek je bio poprište sukoba i ratova, a neki su imali dalekosežne posljedice. Primjerice, atentat koji je Gavrilo Princip izvršio nad Franjom Ferdinandom u Sarajevu bio je povodom za Prvi svjetski rat.
} 
sve u redu k'o u Beču - (all) shipshape and Bristol fashion ${ }^{15}$, to je špansko selo za koga - it's <all> Greek to sb, to je za mene kineski - it's double Dutch to me.

Ova skupina potvrđuje i velik broj frazema s dvije ili više onimske sastavnice i to u oba jezika (ne znam gdje mi je glava - I don't know whether I am Arthur or Martha, svaka šuša - every Tom, Dick and Harry). Tako nasuprot hrvatskome frazemu prelijevanje iz šupljeg u prazno stoji engleski ekvivalent robbing Peter to pay Paul. Pretpostavlja se da se vlastita imena u ovom frazemu odnose na apostole i mučenike, Petra i Pavla, koji su u kršćanskoj umjetnosti često prikazivani kao jednaki (Oxford Dictionary of Idioms 2004: 244). Isto tako, nasuprot engleskome frazemu it's like closing the (barn) door after the horse has gone stoji hrvatski ekvivalent kasno Marko na Kosovo stiže koji je motiviran povijesnim događajem. Naime, kraljević Marko bio je turski vazal koji je u narodu ostao zapamćen kao spasitelj. Narodna epska pjesma zabilježila je zakašnjeli dolazak Marka na Kosovo, na kojem su bosanske, srpske i albanske snage već bile pobijeđene od strane Osmanskog carstva ${ }^{16}$. Hrvatskome frazemu s dva onima proći kao Janko na Kosovu engleski nepodudarni ekvivalent je meet your Waterloo. Ovaj izraz sinonim je za veliku životnu prepreku, nešto vrlo teško savladivo, a povezan je s francuskim osvajačem Napoleonom Bonaparteom kojemu je bitka kod belgijskoga grada Waterlooa označila početak kraja vladavine. Ubrzo nakon tog poraza, slavni engleski pisci George Gordon Byron i Arthur Conan Doyle u svojim su djelima počeli koristili spomenuti frazem ${ }^{17}$.

Uočeni su i parovi hrvatskih i engleskih poredbenih frazema (pušiti kao Turčin - smoke like a chimney, vrvi kao u košnici - it is as busy as Grand Central Station). Među njima se nalaze i nepodudarni frazemi slične pozadinske slike kao drvena Marija - like a cigar-store Indian. Ovaj engleski frazem svoje podrijetlo vuče iz američke kulture, gdje je još od 17. stoljeća uobičajeno da se u trafikama u kojima se prodaju duhanski proizvodi nalaze drvene statue Indijanaca koje su zaštitni znak industrije duhana (američki Indijanci bili su prvi koji su Europljanima „predstavili” duhan) ${ }^{18}$. Hrvatski frazem

15 Ovaj je frazem prvi put zabilježen u 19. stoljeću, a prvotno se odnosio na trgovački uspjeh engleske luke Bristol. Izraz je specifičan za govorno područje Velike Britanije te se uglavnom ne koristi na drugim engleskim govornim područjima (Oxford Dictionary of Idioms 2004: 259).

16 http://vukajlija.com/kasno-marko-na-kosovo-stize (pristupljeno 5. listopada 2018.)

17 www.phrases.org.uk (pristupljeno 3. travnja 2018.)

18 https://www.yourdictionary.com (pristupljeno 20. studenoga 2019.). 
ponavljati kao Švabo tra-la-la - sound like a broken record vjerojatno je motiviran bliskim kontaktom Slavena i Nijemaca te činjenicom da ih Slaveni vrlo često nisu razumjeli što govore. Nijemce se često naziva Švabama, iako i samo ime Nijemac (kao i u drugih slavenskih naroda) znači 'onaj koji ne zna naš jezik, koji je nijem'.

Ova građa obuhvaća i hrvatske frazeme čija je sastavnica posvojni pridjev nastao od vlastitoga imena (dobiti pakrački dekret - get your marching orders, to je za mene kineski; to je za mene špansko selo - it's double Dutch to me). U tom je kontekstu zanimljiv frazem proći pored koga kao pored turskog groblja - cut someone dead značenja 'ne osvrtati se', koji je motiviran islamskom tradicijom prema kojoj posjeta groblju nije uobičajena jer se živi ne osvrću na grobno mjesto.

Ova skupina potvrđuje velik broj engleskih frazema s onimom Dutch (go Dutch, Dutch courage, talk to sb like a Dutch uncle, be (get) in Dutch, it's double Dutch to me) koji su vjerojatno posljedica burnih britansko-nizozemskih ratova tijekom 17. stoljeća nakon kojih su nastali stereotipi (možda čak i predrasude) prema nizozemskome narodu. U ovoj se skupini pojavljuje i engleski frazem get sb's Irish up koji pokazuje da govornici engleskoga govornoga područja (posebice Britanci) doživljavaju Irce kao izrazito nagle i temperamentne ljude.

Zanimljivi su i oni engleski frazemi čija je onimska sastavnica kratko i jednostavno vlastito ime koje predstavlja sinonim za prosječnost i neistaknutost običnog čovjeka, odnosno za tipičnog pripadnika neke skupine, javnosti ili naroda: Katica za sve - a Jack of all trades, običan smrtnik (prosječan gradanin) - the average (ordinary) Joe; Mr. Average; the man on the Clapham omnibus; Joe Bloggs; Joe Blow, svaka šuša - every Tom, Dick and Harry.

Ova skupina također bilježi hrvatske i engleske onimijske frazeme nasuprot kojih stoje frazemi čije su sastavnice fitonimi (biti u neobranom grožđu - be (get) in Dutch, dobiti šipak - get sweet Fanny Adams), zoonimi (kasno Marko na Kosovo stiže - it's like closing the (barn) door after the horse has gone, borba Davida i Golijata - a turkey shoot ${ }^{19}$, pijan kao svinja (guzica) <as> drunk as David's sow) ili pak somatizmi (biti dužan kao Grčka - be up to

19 Frazem se vjerojatno odnosi na lovačku metodu u kojoj lovac pucnjem namjerno rasprši jato divljih purana. Budući da se jato nakon toga vraća na svoje mjesto, lovac čeka divlje purane koji postaju laka meta. Ovaj izraz može se odnositi i na natjecanje u strijeljanju purana iz daljine, a u vojnom žargonu označava zasjedu nespremnog i nenaoružanog neprijatelja kojega je veoma lako poraziti (https://en.wikipedia.org/wiki/Turkey_shoot). U 
your neck in debt, ne znam gdje mi je glava - I don't know whether I am Arthur or Martha, okrenuti leđa komu - send someone to Coventry ${ }^{20}$, živjeti na visokoj nozi; živjeti kao bubreg u loju - live the life of Riley ${ }^{21}$, zabadati (gurati) <svoj> nos <u što $>-$ a nosey Parker).

\section{Tablica 3. Nepodudarni hrvatski i engleski frazemi}

\begin{tabular}{|l|l|}
\hline \multicolumn{1}{|c|}{ Hrvatski frazem } & \multicolumn{1}{c|}{ Engleski frazem } \\
\hline ići cipelcugom & $\begin{array}{l}\text { go (come, get } \text { isl.) by (on) Shank's mare } \\
\text { (pony) }\end{array}$ \\
\hline običan smrtnik; prosječan građanin & $\begin{array}{l}\text { the average (ordinary) Joe; Mr. Average; } \\
\text { the man on the Clapham omnibus; Joe } \\
\text { Blow }\end{array}$ \\
\hline ne znam gdje mi je glava & $\begin{array}{l}\text { I don't know whether I am Arthur or } \\
\text { Martha }\end{array}$ \\
\hline lud sto gradi & <as > mad as a March hare \\
\hline biti u neobranom groždu & be (get) in Dutch \\
\hline dok kažeš keks (britva) & before you can (could) say Jack Robinson \\
\hline vrvi kao u košnici & it is as busy as Grand Central Station \\
\hline ni u ludilu & not on your Nellie \\
\hline visi mač nad glavom komu & $\begin{array}{l}\text { the sword of Damocles hangs over sb's } \\
\text { head }\end{array}$ \\
\hline na svetoga nikada & $\begin{array}{l}\text { on (at) the Greek calends; not in a month } \\
\text { of Sundays }\end{array}$ \\
\hline od pamtivijeka & since the days of Methuselah \\
\hline u rijetke petke & once in a month of Sundays \\
\hline za prvu ruku & as a Band-Aid \\
\hline to je špansko selo za koga & it's <all> Greek to sb \\
\hline
\end{tabular}

svakom slučaju, značenje frazema je neravnopravna borba u kojoj jedna strana ima veliku prednost pred drugom.

20 Pretpostavlja se da je frazem motiviran povijesnim događajem za vrijeme Engleskoga građanskoga rata. Naime, sredinom 17. stoljeća Coventry je bio uporišni grad Parlamenta u Velikoj Britaniji gdje su rojalistički zatvorenici odvođeni s namjerom da budu ignorirani i zapostavljeni (https://www.phrases.org.uk).

21 Ovaj frazem američkoga podrijetla prvi put se spominje početkom 20. stoljeća. Neki izvori bilježe spominjanje imena Riley u vodviljima, no izraz se najvjerojatnije raširio tijekom Prvoga svjetskoga rata diljem američkih kampova, kada su vojnici u pismima svojim obiteljima popularizirali ovaj izraz (https://grammarist.com). 


\begin{tabular}{|l|l|}
\hline \multicolumn{1}{|c|}{ Hrvatski frazem } & \multicolumn{1}{|c|}{ Engleski frazem } \\
\hline raditi kao sivonja & work like a dog (Trojan) \\
\hline pijan kao svinja (guzica) & <as> drunk as David's sow \\
\hline dobiti šipak & get sweet Fanny Adams \\
\hline nema <tu> trte-mrte & no more Mr. Nice Guy \\
\hline ne zna se tko pije ni tko plaća & it's a Chinese fire drill \\
\hline dignuti živac komu & get sb's Irish up \\
\hline dići kuku i motiku & raise Cain \\
\hline graditi kule u zraku (oblacima) & build castles in Spain \\
\hline smijati se od uha do uha & grin like a Cheshire cat \\
\hline svi šefuju, a nitko ne radi & too many chiefs (and not enough Indians) \\
\hline soliti more & $\begin{array}{l}\text { take coals to Newcastle; sell ice to the } \\
\text { Eskimos }\end{array}$ \\
\hline gutljaj za hrabrost; hrabrost iz flaše & Dutch courage \\
\hline okrenuti leđa komu & send someone to Coventry \\
\hline ne govoriti napamet & not (just) whistle Dixie \\
\hline pola-pola; fifti-fifti & go Dutch \\
\hline $\begin{array}{l}\text { to je za mene kineski; to je za mene } \\
\text { špansko selo }\end{array}$ & it's double Dutch to me \\
\hline $\begin{array}{l}\text { živjeti na visokoj nozi; živjeti kao bubreg u } \\
\text { loju }\end{array}$ & live the life of Riley \\
\hline prava stvar & the real McCoy \\
\hline zabadati (gurati) <svoj> nos <u što> & a nosey Parker \\
\hline prelijevanje iz šupljeg u prazno & robbing Peter to pay Paul \\
\hline lako je biti general poslije bitke & a Monday morning quarterback \\
\hline sve u redu k’o u Beču & (all) shipshape and Bristol fashion \\
\hline biti (naći se) u gabuli; biti u škripcu & be in Queer Street \\
\hline bablje ljeto & an Indian summer; Saint Martin's summer \\
\hline ni za sve blago svijeta; ni za živu glavu & not for all the tea in China \\
\hline svaka šuša & every Tom, Dick and Harry \\
\hline soliti komu pamet; dijeliti komu lekcije & talk to sb like a Dutch uncle \\
\hline diže se kosa <na glavi> komu <od čega> & Greek meets Greek \\
\hline otkriti/otkrivati Ameriku & discover (reinvent) the wheel \\
\hline star kao Biblija & as old as Methuselah \\
\hline i mirna Bosna & set the world to rights \\
\hline ispraviti/ispravljati krivu Drinu & \\
\hline
\end{tabular}




\begin{tabular}{|l|l|}
\hline \multicolumn{1}{|c|}{ Hrvatski frazem } & \multicolumn{1}{c|}{ Engleski frazem } \\
\hline praviti se Englez (Kinez, Tošo) & play dumb \\
\hline biti dužan kao Grčka & be up to your neck in debt \\
\hline proći (provesti se) kao Janko na Kosovu & meet your Waterloo \\
\hline Katica (djevojka) za sve & $\begin{array}{l}\text { a girl (man, person) Friday; a Jack of all } \\
\text { trades }\end{array}$ \\
\hline pričati (pripovijedati i sl.) Markove konake & talk at large \\
\hline u Adamovu kostimu & in his birthday suit \\
\hline u Evinu kostimu & in her birthday suit \\
\hline od Kulina bana & since the days of Methuselah \\
\hline za Kulina bana & in old (ancient) times \\
\hline kao drvena Marija & like a cigar-store Indian \\
\hline ravno je sve do mora (Kosova) komu & sb could care less \\
\hline $\begin{array}{l}\text { stajati (koštati) <koga> kao svetog Petra } \\
\text { kajgana }\end{array}$ & cost <sb> an arm and a leg \\
\hline to je <kao> Sveto pismo <za koga> & it is <like> gospel <truth> to sb \\
\hline ići (hodati i sl.) od Poncija do Pilata & go from pillar to post \\
\hline slati koga od Poncija do Pilata & send sb from pillar to post \\
\hline ponavljati kao Švabo tra-la-la & sound like a broken record \\
\hline borba Davida i Golijata & a turkey shoot \\
\hline dobiti pakrački dekret & get your marching orders \\
\hline proći pored koga kao pored turskog groblja & cut someone dead \\
\hline (morati) sve opet Jovo nanovo & go back to square one \\
\hline kasno Marko na Kosovo stiže & $\begin{array}{l}\text { it's like closing the (barn) door after the } \\
\text { horse has gone }\end{array}$ \\
\hline Martin u Zagreb, Martin iz Zagreba & come back none the wiser \\
\hline noga lička, a cipela bečka & $\begin{array}{l}\text { you can take the boy out of the village, but } \\
\text { you can't take the village out of the boy }\end{array}$ \\
\hline kao da je pao s Marsa & $\begin{array}{l}\text { as if (though) sb had come from another } \\
\text { planet }\end{array}$ \\
\hline pušiti kao Turčin & smoke like a chimney \\
\hline puno (mnogo) je vode proteklo <Savom> & a lot of water has flowed under the bridge \\
\hline
\end{tabular}




\section{Zaključak}

Kontrastivnom analizom pokazalo se kako je najveća skupina hrvatskih i engleskih frazema s potpunom nepodudarnošću frazeološkog izraza (57,4\%), nakon čega slijedi skupina potpuno podudarnih hrvatskih i engleskih onimijskih frazema (36,4\%), dok je djelomično podudarnih hrvatskih i engleskih frazema najmanje (6,2\%). Unutar skupine potpuno podudarnih hrvatskih i engleskih onimijskih frazema najviše je mitološki motiviranih frazema, nakon kojih slijede biblijski frazemi te frazemi motivirani nekom povijesnom činjenicom. Skupina djelomično podudarnih hrvatskih i engleskih onimijskih frazema broji dva biblijski motivirana frazema i jedan frazem mitološkoga podrijetla. U skupini potpuno nepodudarnih hrvatskih i engleskih onimijskih frazema prevladavaju frazemi koji nisu vezani uz biblijsku, mitološku ili povijesnu priču, ili im je podrijetlo nepoznato. Zatim slijede frazemi povijesnog $\mathrm{i}$ biblijskog podrijetla, a najmanje je mitološki motiviranih frazema.

Može se zaključiti da frazemi s onimskom sastavnicom oslikavaju ne samo ljudske osobine i životne dogodovštine koje se u većini slučajeva metaforički zrcale kroz prizmu povijesnih, biblijskih i mitoloških ličnosti i događaja, već takvi frazemi upotpunjavaju i obogaćuju frazeološke fondove brojnih jezika te na taj način zbližavaju i učvršćuju (zajedničku) povijest njihovih jezika i kultura. Osim frazema koji su zajednički velikome broju jezika, za društvene i humanističke znanosti iznimno su dragocjeni i nacionalni frazemi za koje se može reći da su vjeran pokazatelj posebnosti naroda u kojem su nastali, a iz čijih je onimskih sastavnica moguće iščitati njihove običaje, mitove, iskustva, ali i percipiranje drugih naroda i njihovih specifičnosti.

Analiza prikupljene frazeološke građe može se sažeti u prikladnu konceptualnu metaforu - NOMEN EST OMEN. Ime zaista jest znamenje, kako za pojedince, tako i za narode čija ukupnost iskustava i spoznaja kroji bogatstvo nekoga jezika te ga čini trajnim pokazateljem povijesti čovječanstva.

\section{Literatura}

Barac-Grum, Vida (1990) „Mogućnosti preobrazbe vlastitog imena”, Rasprave Zavoda za jezik, 16, 1, 15-20.

Brdar, Mario; Brdar-Szabó, Rita (2001) „Vlastita imena između metonimijske Scile i metaforičke Haribde", Rasprave Instituta za hrvatski jezik i jezikoslovlje, 27, 31-48. 
Brozović Rončević, Dunja, Žic Fuchs, Milena (2003/2004) „Metafora i metonimija kao poticaj u procesu imenovanja”, Folia onomastica Croatica, 12-13, 91-104.

Ivanetić, Nada, Karlavaris-Bremer Ute (1999) „Onimijski frazemi i konceptualizacija svijeta”, Suvremena lingvistika, 47-48, 1, 131-142.

Lakoff, George; Johnson, Mark (1980); Metaphors We Live By, Chicago and London: University of Chicago Press, str. 3-9.

Marković, Ivan (2010) „O uporabi i značenju imenâ u hrvatskome”, Folia onomastica Croatica, 19, 175-202.

Menac, Antica (2007) Hrvatska frazeologija, Knjigra, Zagreb.

Opašić, Maja (2014) „Mogućnosti deonimizacije i apelativizacije biblijskih onima u hrvatskome jeziku", Riječki filološki dani, 9, 501-510.

Opašić, Maja (2014) „Općeeuropski frazemi hrvatskoga jezika u Rječniku stranih riječi Bratoljuba Klaića”, Rasprave Instituta za hrvatski jezik i jezikoslovlje, 40, 2, 411-434.

Peti, Mirko (1999) „O tzv. sadržaju imena”, Folia onomastica Croatica, 8, 97-121.

Stanojević, Mateusz Milan (2013) Konceptualna metafora: temeljni pojmovi, teorijski pristupi i metode, Srednja Europa, Zagreb.

Turk, Marija (1994) „Naznake o podrijetlu frazema”, Fluminensia, 6, 1-2, 37-47.

Vuković, Siniša (2007) „Onomastička terminologija”, Čakavska rič, 35, 1, 139-185.

\section{Rječnici}

Anić, Vladimir; Goldstein, Ivo (2000) Rječnik stranih riječi, Novi liber, Zagreb.

Anić, Vladimir (2006) Veliki rječnik hrvatskoga jezika, Novi liber, Zagreb.

Bendow, Ivana (2006) Englesko-hrvatski frazeološki rječnik, Školska knjiga d.d., Zagreb.

Bendow, Ivana (2009) Hrvatsko-engleski frazeološki rječnik, Školska knjiga d.d., Zagreb.

Cambridge International Dictionary of Idioms 2002. (ur. Elizabeth Walter), United Kingdom: Cambridge University Press. 
Filipović, Rudolf (1999) Englesko-hrvatski rječnik, Školska knjiga, Zagreb.

HER (2002) Hrvatski enciklopedijski rječnik, Novi Liber, Zagreb.

Klaić, Bratoljub (1984) Rječnik stranih riječi, Nakladni zavod Matice hrvatske, Zagreb.

Longman Pocket Idioms Dictionary 2001. China: Pearson Education.

Menac, Antica; Fink-Arsovski, Željka; Venturin, Radomir (2014) Hrvatski frazeološki rječnik, Naklada Ljevak, Zagreb.

Oxford Dictionary of Idioms 2004. (ur. Judith Siefring), New York: Oxford University Press.

Oxford Advanced Learner's Dictionary 2010. (ur. Joanna Turnbull), London: Oxford University Press.

Vrgoč Dalibor; Fink-Arsovski, Željka (2008) Hrvatsko-engleski frazeološki rječnik, Naklada Ljevak, Zagreb.

\section{Izvori}

http://www.phrases.org.uk (pristupljeno 23. veljače 2019.)

http://hjp.novi-liber.hr (pristupljeno 20. ožujka 2019.)

http://www.thefreedictionary.com (pristupljeno 15. prosinca 2018.)

http://dictionary.reference.com (pristupljeno 7. travnja 2018.)

http://vukajlija.com/kasno-marko-na-kosovo-stize (pristupljeno 9. ožujka 2019.)

https://grammarist.com (pristupljeno 20. studenoga 2019.) https://www.yourdictionary.com (pristupljeno 20. studenoga 2019.). http://www.enciklopedija.hr (pristupljeno 20. studenoga 2019.)

http://www.intimatemedicine.com.hr/enciklopedija-seksualnosti/ partnerski-odnosi/partnerski-problemi/zenskar/tko-su-don-juanikoji-osvajaju-zene (pristupljeno 21. studenoga 2019.)

http://mentalfloss.com/article/52989/what\%E2\%80\%99s-origin\%E2\%80\%9Cchinese-fire-drills (pristupljeno 8. travnja 2018.)

https://en.wikipedia.org/wiki/Turkey_shoot (pristupljeno 7. svibnja 2018.) 


\section{SUMMARY}

Dunja Zoričić

\section{NOMEN EST OMEN. CONTRASTIVE ANALYSIS OF CROATIAN AND ENGLISH PHRASEMES WITH AN ONYMIC COMPONENT}

In this paper we analyse Croatian and English phrasemes with an onymic component, which can either have a status of a toponym, an ethnonym, or an anthroponym. The aim of the paper is to determine the similarities and the differences between Croatian and English onymic phrasemes using contrastive analysis. Additionally, Croatian and English are observed as two spatially and genealogically distant languages. This is done in order to identify the differences and peculiarities conditioned by cultural, social, political, historical or some other features. This paper compares two cultures with different histories and sociolinguistic backgrounds, one Anglo-Saxon, the other Slavic. The analysis has shown that phrasemes with onymic components can be divided into three groups.

The first group consists of corresponding Croatian and English onymic phrasemes, which means both phrasemes contain an identical proper name, lexically as well as structurally equal phrase, and the same motivation for the figurative meaning, i.e. background. The second group consists of phrasemes that contain an identical proper name but are partially different in phrase structure. The last group consists of Croatian and English phrasemes that share the same meaning, but differ in phrase structure, the onymic component, and background. The analysis has revealed that the third group was the largest (57,4\%).

It can be concluded that phrasemes with an onymic component represent not only human traits and life adventures, which are mostly metaphorically mirrored through the prism of historical, biblical, and mythological personalities or events, but that such phrasemes also complement and enrich phraseology of many languages, thus bringing together and strengthening the (shared) history of their nations and cultures. In addition to phrasemes common to numerous languages, national phrasemes are extremely valuable because they are a reliable indicator of the peculiarities of a nation from which they originate, and their constituent elements reflect the customs, beliefs, experiences, but also the perception of other nations and their specificities.

Key words: Croatian language; English language; phraseme; phraseology; contrastive analysis; proper name 